was "five times more than any other country" had shared and "more than Russia and China." 58 Biden said:

[T]here's a lot of talk about Russia and China influencing the world with vaccines. We want to lead the world with our values - with this demonstration of our innovation, ingenuity, and the fundamental decency of the American people... .

We'll share these vaccines in the service of ending the pandemic everywhere. And we will not use our vaccines to secure favors from other countries. 59

Biden and his deputies have repeatedly said that U.S.-donated vaccines would be free and would come with "no demands, no conditions, no coercion attached," apparently drawing a contrast to Russia and China. ${ }^{60}$ Scientists and health officials have questioned the efficacy of the Chinese-made shots, leading some Southeast Asian countries that received China's vaccines to seek doses from Western drug-makers such as Moderna and Johnson \& Johnson. ${ }^{61}$ The demand has created a diplomatic opening for the United States in the region to send vaccine donations. ${ }^{62}$

Vaccination efforts are racing against the emergence and spread of new variants. As of late August, the worldwide tallies stood at more than 216 million confirmed cases of COVID-19 infections, 4.5 million deaths, and some five billion vaccine doses administered. ${ }^{63}$

\title{
INTERNATIONAL Human Rights AND HumanitaRian Law
}

\section{U.S. Supreme Court Holds Claims Against U.S. Corporations for Aiding and Abetting Child Slavery Impermissibly Extraterritorial, Declines to Resolve Domestic Corporate Liability doi:10.1017/ajil.2021.53}

In Nestlé USA, Inc. v. Doe, et al., former child slaves who were trafficked into Côte d'Ivoire to work on cocoa farms filed suit under the Alien Tort Statute (ATS) against U.S.-based companies that purchase cocoa from and provide other support to the farms, alleging that the companies aided and abetted child slavery. By an 8-1 vote, the Supreme Court held that

\footnotetext{
${ }^{58}$ White House Press Release, Remarks by President Biden on the COVID-19 Response and the Vaccination Program (May 17, 2021), at https://www.whitehouse.gov/briefing-room/speeches-remarks/2021/05/17/ remarks-by-president-biden-on-the-covid-19-response-and-the-vaccination-program-4 [https://perma.cc/ HLX7-3BCT].

${ }^{59} \mathrm{Id}$.

${ }^{60}$ White House Press Release, Remarks by President Biden on Fighting the COVID-19 Pandemic (Aug. 3, 2021), at https://www.whitehouse.gov/briefing-room/speeches-remarks/2021/08/03/remarks-by-presidentbiden-on-fighting-the-covid-19-pandemic [https://perma.cc/PW7F-S2BU].

${ }^{61}$ E.g., Sui-Lee Wee \& Steven Lee Myers, As Chinese Vaccines Stumble, U.S. Finds New Opening in Asia, N.Y. Times (Aug. 20, 2021), at https://www.nytimes.com/2021/08/20/business/economy/china-vaccine-us-coviddiplomacy.html.

${ }^{62} \mathrm{Id}$.

63 WHO Coronavirus (COVID-19) Dashboard, at https://covid19.who.int (last visited Aug. 31, 2021).
} 
the case involved an impermissible extraterritorial application of the ATS under the Court's precedent in Kiobel. ${ }^{1}$ The Court declined to resolve whether domestic corporations may be held liable under the ATS, although five justices across several opinions expressed the view that such corporations are not immune from ATS suits. The question of whether the Court should ever create new causes of action under the ATS prompted significant debate, with three justices suggesting that they would overrule Sosa v. Alvarez-Machain and a fourth indicating that there are strong arguments to reject judicial creation of any new ATS causes of action.

The former child slaves initially filed the case as a class action against U.S. and foreign corporations, alleging that the companies aided and abetted child slavery in Côte d'Ivoire and were thus liable for violations of the law of nations. ${ }^{2}$ After the Supreme Court held in Kiobel that the ATS does not rebut the presumption against extraterritoriality, ${ }^{3}$ the district court dismissed the case. ${ }^{4}$ Following the Supreme Court's decision in Jesner v. Arab Bank, PLC that foreign corporations cannot be liable under the ATS, ${ }^{5}$ the Ninth Circuit reversed in part, upholding the dismissal of the foreign corporations but allowing the claims against U.S. corporations Nestlé USA and Cargill to proceed. ${ }^{6}$ As to the U.S. companies, the Ninth Circuit held that the plaintiffs pleaded a domestic, not an extraterritorial, application of the ATS because the companies made "financing decisions" in the United States, and "the allegations paint a picture of overseas slave labor ... perpetuated from headquarters in the United States."

The Supreme Court granted and consolidated Nestlé and Cargill's petitions for certiorari, ${ }^{8}$ which asked the Court to decide whether general corporate activity in the United States, related to harms abroad, constituted a domestic application of the ATS and whether the judiciary may make domestic corporations liable under the ATS. ${ }^{9}$ In their merits briefs, Nestle and Cargill argued that the plaintiffs failed to rebut the presumption against extraterritoriality because the conduct that is the focus of the ATS occurred abroad. ${ }^{10}$ The United States filed an amicus brief supporting the companies and similarly argued that because "the alleged principal conduct occurred entirely overseas, respondents' claims are impermissibly extraterritorial." 11

On corporate liability, Nestlé and Cargill argued that domestic corporations cannot be held liable under the ATS. Drawing on "Sosa and Jesner's two-step test," 12 they argued

${ }^{1}$ Nestlé USA, Inc. v. Doe, 141 S. Ct. 1931, 1933 (2021).

${ }^{2} I d$. at 1935.

${ }^{3}$ See John R. Crook, Contemporary Practice of the United States, 107 AJIL 650, 651-52 (2013).

${ }^{4}$ Nestlé v. Nestlé, S.A., No. CV 05-5133-SVW-MRW, 2017 WL 6059134 (C.D. Cal. Mar. 2, 2017).

${ }^{5}$ See Rebecca J. Hamilton, Jesner v. Arab Bank, 138 S. Ct. 1386, United States Supreme Court, April 24, 2018, 112 AJIL 720, 720 (2018).

${ }^{6}$ Doe v. Nestlé, S.A., 906 F.3d 1120, 1124 (9th Cir. 2018).

${ }^{7}$ Id. at 1126.

${ }^{8}$ Cargill, Inc. v. Doe, 141 S. Ct. 184 (2020).

${ }^{9}$ See Petition for Writ of Certiorari at I, Nestlé USA, Inc. v. Doe, 141 S. Ct. 1931 (2021) (No. 19-416).

${ }^{10}$ Brief For Petitioners Nestlé USA, Inc. at 15, 19-21, Nestlé USA, Inc. v. Doe, 141 S. Ct. 1931 (2021) (No. 19-416) [hereinafter Nestlé Brief]; see also Brief For Petitioners Cargill, Inc. at 22, 24-25, Nestlé USA, Inc. v. Doe, 141 S. Ct. 1931 (2021) (No. 19-453) [hereinafter Cargill Brief].

${ }^{11}$ Brief for the United States as Amicus Curiae Supporting Petitioners at 30-31, Nestlé USA, Inc. v. Doe, 141 S. Ct. 1931 (2021) (No. 19-416) [hereinafter U.S. Amicus Brief].

${ }^{12}$ Nestlé Brief, supra note 10 , at 35. 
that "there is no specific, universal, obligatory international norm of corporate liability,"13 and that even if such a norm existed, "every cautionary factor that counseled against creating a cause of action against foreign corporations in Jesner applies equally to domestic corporations." 14 In particular, the companies highlighted separation of powers concerns about judicial creation of causes of action and foreign relations risks. ${ }^{15}$

In a reversal from its position in Kiobel and Jesner, ${ }^{16}$ the United States joined the companies in arguing against corporate liability under the ATS. ${ }^{17}$ The United States argued that the Court need not determine "whether Sosa's first step forecloses domestic-corporation liability, . . . as Sosa's second step plainly does so." 18 The United States asserted that judicial creation of a cause of action for domestic corporations, without action from Congress, would raise separation of powers concerns,${ }^{19}$ and may "interfere with U.S. foreign-policy priorities," including by "undermin[ing] the strategies preferred by the Executive and Congress for addressing particular issues." 20

For their part, the respondents argued that the "ATS' text excludes no category of defendants" and its purpose would be "undermined by immunizing U.S. corporations." 21 The respondents also argued that their claims do not involve an impermissible extraterritorial application of the ATS because the text, history, and purpose of the statute was to provide a "forum for foreign nationals to bring tort claims for violations of the law of nations," a standard that aiding and abetting meets. ${ }^{22}$ Additionally, they argued that their claims satisfy Kiobels "touch and concern" test because the relevant actions were done by U.S. defendants on U.S. soil. ${ }^{23}$

The case prompted a fractured set of four opinions. In the portion of Justice Thomas's opinion that garnered eight votes, the Court held that the case involved an impermissible extraterritorial application of the ATS and thus dismissed the case on this ground, reversing the Ninth Circuit. ${ }^{24}$ Applying its two-step test for analyzing extraterritoriality, the Court reaffirmed its holding in Kiobel that the ATS does not rebut the presumption against extraterritorial application. ${ }^{25}$ At the second step of the extraterritoriality inquiry, the Court explained

${ }^{13}$ Id. at 39; see also Cargill Brief, supra note 10, at 41-43.

${ }^{14}$ Nestlé Brief, supra note 10 , at 39.

${ }^{15}$ Id. at 40-48; Cargill Brief, supra note 10, at 43-46.

${ }^{16}$ See William S. Dodge, Trump Administration Reverses Position on Corporate Liability Under Alien Tort Statute. Just SECURITY (June 1, 2020), at https:/www.justsecurity.org/70512/trump-administration-reverses-positionon-corporate-liability-under-alien-tort-statute.

${ }_{17}$ The United States explained that it "revisited its position in light of the Jesner opinion, which rejected not only the government's conclusion but also its basic framework for analysis." U.S. Amicus Brief, supra note 11, at 12 n.3.

${ }^{18} \mathrm{Id}$. at $11-12$.

$19 \mathrm{Id}$. at $12-14$.

${ }^{20} \mathrm{Id}$. at 7; see also id. at $15-20$.

${ }^{21}$ Brief for Respondents at 36, Nestlé USA, Inc. v. Doe, 141 S. Ct. 1931 (2021) (No. 19-416) [hereinafter Respondents' Brief].

${ }^{22} I d$. at 9 .

${ }^{23} \mathrm{Id}$.

${ }^{24}$ Nestlé USA, Inc. v. Doe, 141 S. Ct. 1931, 1935-36 (2021).

${ }^{25}$ Id. at $1936-37$. 
that the respondents' claim does not establish that "the conduct relevant to the statute's focus occurred in the United States." ${ }^{26}$ Instead, the relevant conduct for the tort of aiding and abetting child slavery occurred solely in Côte d'Ivoire. ${ }^{27}$ The Court rejected the respondents' claim that the relevant conduct was corporate activity in the United States, explaining that "allegations of general corporate activity-like decisionmaking-cannot alone establish domestic application of the ATS." 28 As applied to the facts before it, the Court held that the respondents' "generic allegations of . . . [making 'operational decisions'] do not draw a sufficient connection between the cause of action respondents seek-aiding and abetting forced labor overseas - and domestic conduct." 29

The only justice to dissent from the extraterritoriality holding was Justice Alito, who explained that he would have vacated and remanded rather than answering the extraterritoriality question because doing so required the majority to assume the answers to important questions, such as whether courts should recognize new causes of action under the ATS. ${ }^{30}$

Although Nestle marked the third time the Court has granted review of whether corporations are subject to ATS liability, the Court again declined to resolve the issue for U.S. corporations. In separate opinions, however, five justices indicated that there is no categorical bar to suing domestic corporations under the ATS. In a concurrence joined in relevant part by Justice Alito, Justice Gorsuch relied on the statute's text and history to explain that "nothing in the ATS supplies corporations with special protections against suit." ${ }^{11}$ Gorsuch argued that when the First Congress adopted the ATS, the law generally allowed suits against corporations for torts and that "distinguishing between individuals and corporations would seem to make little sense" given that the offenses motivating Congress, particularly assaults against ambassadors and piracy, could be perpetrated by individuals or corporations. ${ }^{32}$ Justice Alito also noted in his dissent that "[c]orporate status does not justify special immunity." 33 In concurring in part and in the judgment, Justice Sotomayor, joined by Justices Breyer and Kagan, approvingly cited the corporate liability portion of Justice Gorsuch's concurrence and explained that "there is no reason to insulate domestic corporations from liability for lawof-nations violations simply because they are legal rather than natural persons." 34

Large portions of the opinions in Nestle focus on an issue that was not among the questions presented in the case, namely whether to reconsider the Court's holding in Sosa that the judiciary may recognize new causes of action under the ATS in limited circumstances. Justices Thomas, Gorsuch, and Kavanaugh appear prepared to overrule Sosa's direction that courts may recognize new causes of action, subject to vigilant doorkeeping, and Justice Alito noted that they raise strong arguments.

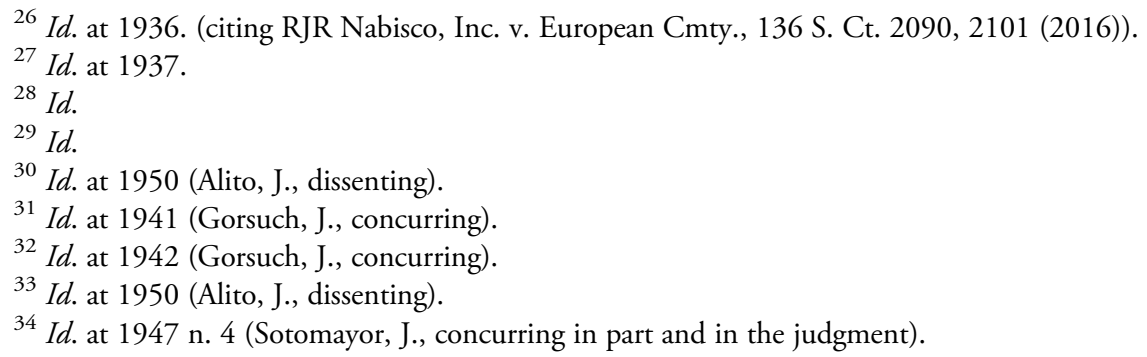


In a portion of his opinion joined only by Justices Gorsuch and Kavanaugh, Justice Thomas argued that "[w] cannot create a cause of action" to allow respondents to sue because "[t]hat job belongs to Congress, not the Federal Judiciary." 35 Thomas noted that the Court's decisions following Sosa "clarified that courts must refrain from creating a cause of action whenever there is even a single sound reason to defer to Congress," 36 and he argued that there is always a reason to defer in ATS cases. Thomas explained that "[a]lthough specific foreign-policy concerns may vary from case to case, our precedents are clear that creating a cause of action to enforce international law beyond three historical torts" of violations of safe conduct, attacks on ambassadors, and piracy "invariably gives rise to foreign-policy concerns." 37 Noting that "[n]obody here has expressly asked us to revisit Sosa," Thomas concluded:

Under existing precedent, then, courts in some circumstances might still apply Sosa to recognize causes of action for the three historical torts likely on the mind of the First Congress. But as to other torts, our precedents already make clear that there always is a sound reason to defer to Congress, so courts may not create a cause of action for those torts. Whether and to what extent defendants should be liable under the ATS for torts beyond the three historical torts identified in Sosa lies within the province of the Legislative Branch. ${ }^{38}$

Justice Gorsuch, joined in relevant part by Justice Kavanaugh, went further in arguing that "the power to create a cause of action is in every meaningful sense the power to enact a new law . . . . And our Constitution generally assigns that power to Congress." 39 Noting that the Court has not recognized a new cause of action in the nearly two decades since Sosa, despite "thoughtful and able" lawyering, Gorsuch argued that he "would stop feigning some deficiency in these offerings" and recognize that "[h]owever vigilant the doorkeeper, the truth is this is a door Sosa should not have cracked." 40 Like Thomas, Gorsuch cited foreign policy concerns, arguing that " $[\mathrm{w}]$ ere we to create new causes of action, we would risk doing exactly what Congress adopted the ATS to avoid: complicating or even rupturing this Nation's foreign relationships." 41 Clarifying that the Court will not recognize new causes of action would, according to Gorsuch,

have other virtues too. It would get this Court out of the business of having to parse out ever more convoluted reasons why it declines to exercise its assumed discretion to create new ATS causes of action. It would absolve future parties from years of expensive and protracted litigation destined to yield nothing. It would afford everyone interested in these matters clear guidance about whom they should lobby for new laws. It would

${ }^{35} I d$. at 1937.

${ }^{36} I d$.

${ }^{37}$ Id. at 1939.

${ }^{38} \mathrm{Id}$. at 1940.

${ }^{39} \mathrm{Id}$. at 1942 (Gorsuch, J., concurring) (emphasis in original).

${ }^{40} \mathrm{Id}$. at 1943 (Gorsuch, J., concurring).

${ }^{41}$ Id. (Gorsuch, J., concurring). 
avoid the false modesty of adhering to a precedent that seized power we do not possess in favor of the truer modesty of ceding an ill-gotten gain. And it would clarify where accountability lies when a new cause of action is either created or refused: With the people's elected representatives. ${ }^{42}$

In dissent, Justice Alito noted that Justices Thomas and Gorsuch "make strong arguments that federal courts should never recognize new claims under the ATS," but as the petitioners' counsel did not raise this argument, Justice Alito would not opine further. ${ }^{43}$

Justice Sotomayor, joined by Justices Breyer and Kagan, joined the Court's opinion concerning the extraterritorial application of the ATS, but opposed Justice Thomas's attempt to overrule Sosa "in all but name." ${ }^{44}$ Justice Sotomayor disagreed with Thomas's application of Sosa's second step, calling his approach "unmoored from both history and precedent." ${ }^{5}$ She instead explained that " $[\mathrm{t}]$ he First Congress made the legislative determination that a remedy should be available under the ATS ... [and] [b]arring some extraordinary collateral consequence that could not have been foreseen by Congress, federal courts should not, under the guise of judicial discretion, second-guess that legislative determination." 46 "Respect for the separation of powers," she argued, "is hardly served by refusing a legislatively assigned task." ${ }^{77}$ Justice Sotomayor also rejected Justice Thomas's foreign policy concerns, calling his proposed bar on recognizing new causes of action a "gross overreaction to a manageable (and largely hypothetical) problem." 48 She instead noted that courts could use "limits on personal jurisdiction, case-by-case deference to the political branches, and the doctrines of exhaustion, forum non conveniens, and international comity" to manage any such friction, and further accused Thomas of "ignor[ing] the other side of the equation: that foreign nations may take ... umbrage at the United States' refusal to provide redress to their citizens for international law torts committed by U.S. nationals within the United States." 49

Whether the Court is likely to overrule Sosa remains unclear. Chief Justice Roberts and Justice Barrett joined only the majority portion of Justice Thomas's opinion on extraterritoriality, and thus did not express a view about Sosa. Even without overruling Sosa, however, Nestlé poses a significant impediment to ATS litigation going forward. ${ }^{50}$

${ }^{42} I d$. (Gorsuch, J., concurring).

${ }^{43}$ Id. at 1951 (Alito, J., dissenting).

${ }^{44} I d$. at 1944 (Sotomayor, J., concurring in part and in the judgment).

${ }^{45} \mathrm{Id}$. at 1945 (Sotomayor, J., concurring in part and in the judgment).

${ }^{46} \mathrm{Id}$. at 1946 (Sotomayor, J., concurring in part and in the judgment).

${ }^{47} \mathrm{Id}$. at 1947 (Sotomayor, J., concurring in part and in the judgment).

${ }^{48} \mathrm{Id}$. at 1948 (Sotomayor, J., concurring in part and in the judgment).

${ }^{49} \mathrm{Id}$. (Sotomayor, J., concurring in part and in the judgment).

${ }^{50}$ See, e.g., William S. Dodge., The Surprisingly Broad Implications of Nestlé USA, Inc. v. Doe for Human Rights Litigation and Extraterritoriality, JUST SECURITY (June 18, 2021), at https://www.justsecurity.org/77012/the-surprisingly-broad-implications-of-nestle-usa-inc-v-doe-for-human-rights-litigation-and-extraterritoriality; Beth Van Schaack, Nestle \& Cargill v. Doe: What's Not in the Supreme Court's Opinions, Just SeCuriTy (June 30, 2021), at https://www.justsecurity.org/77120/nestle-cargill-v-doe-whats-not-in-the-supreme-courts-opinions. 